\title{
Changes in Metabolism of Rat Kidney and Liver Caused by Experimental Diabetes and by Dietary Sucrose
}

\author{
S.S. Kang ${ }^{1}$, R. Fears ${ }^{2}$, S. Noirot ${ }^{1}$, J. N. Mbanya ${ }^{1}$ and J. Yudkin ${ }^{1}$ \\ ${ }^{1}$ Department of Nutrition, Queen Elizabeth College, London and ${ }^{2}$ Beecham Pharmaceuticals Research Division, Epsom, Surrey, UK
}

Summary. Two groups of rats were fed diets in which the carbohydrate component was either starch or sucrose. A third group was fed on a stock diet. Half of the animals in each group were made diabetic by injection of either streptozotocin, in two of the groups, or alloxan, in the third group.

Both diabetes and sucrose-feeding increased renal gluconeogenesis as indicated by increased activities of fructose-1,6-diphosphatase and glucose-6phosphatase. Sucrose-feeding increased fatty acid synthesis both in the liver and kidney. However, the effect of diabetes on fatty acid synthesis was different at the two tissue sites. Diabetes, whether induced by streptozotocin or alloxan, decreased fatty acid synthesis in the liver but increased the rate in the kidney. The latter response was obtained for each diet but was additive with the effect of sucrose.

We conclude that the effect of diabetes on renal lipid metabolism may reflect, in part, the accelerated glucose flux. The response to both diabetes and sucrose-feeding is also possibly associated with the increased lipid required for the membrane synthesis reported previously.

Key words: Streptozotocin-diabetes, sucrose-diet, alloxan-diabetes, lipogenesis, lipogenic enzymes, gluconeogenic enzymes, kidney, liver, rat, kidney lipids.

We have shown previously that the consumption of sucrose-rich diets by rats results in kidney glomerular basement membrane thickening that resembles the effect of diabetes [1]. Comparatively little is known concerning the relative effects of sucrose-feeding and diabetes on intermediary metabolism in the kidney, whereas it is established that dietary sucrose and dia- betes have converse effects on hepatic lipogenesis [2-5] but qualitatively similar effects on gluconeogenesis [6-8]. It was the purpose of the present experiments to examine the effects of diabetes and sucrosefeeding on renal carbohydrate and lipid metabolism, comparing the response with changes in the liver where appropriate, in an attempt to obtain further information concerning the deterioration in kidney function observed in these metabolic states.

\section{Materials and Methods}

\begin{abstract}
Animals
Three experiments were performed. In the first and second experiment, male Wistar rats weighing between 170 and $200 \mathrm{~g}$ were fed on a reconstituted diet containing corn starch $(68 \%)$ or sucrose $(68 \%)$ [2] for a period of 25-30 days. In the third experiment, male Sprague-Dawley rats $(180-200 \mathrm{~g})$ were fed on a stock pelleted diet (Oxoid Breeding diet, Betchworth, Surrey). Half the rats in each dietary group were made diabetic. In experiments 1 and 2 , this was done 2 days after the beginning of the experiment by injection of streptozotocin into the tail vein $(65 \mathrm{mg} / \mathrm{kg}$ body weight); these rats were thus diabetic for 23-28 days before the experiments were ended.

In experiment 3, diabetes was induced by the injection of alloxan $(45 \mathrm{mg} / \mathrm{kg}$ body weight $) 2$ days before the experiment was ended. The conditions for the third experiment were chosen to be different from the first two experiments to determine the consistency of the effect of diabetes on lipid synthesis. Food and water were administered ad libitum and rats were killed between 10.00 and $12.00 \mathrm{~h}$.
\end{abstract}

\section{Analytical Methods}

Serum glucose was analysed by a glucose oxidase method (GODPAP method, Boehringer Mannheim, FRG), insulin by the doubleantibody method of Hales and Randle [9] using a human insulin standard. Total lipids were estimated in the kidney homogenate by the sulfovanillin reaction (Total lipids, Boehringer Mannheim, FRG). 
Table 1. Plasma glucose and insulin levels and kidney enzyme activities in normal and diabetic rats fed stock or sucrose diet

\begin{tabular}{|c|c|c|c|c|c|c|c|}
\hline Rats & $\begin{array}{l}\text { Plasma } \\
\text { glucose } \\
(\mathrm{mmol} / \mathrm{l})\end{array}$ & $\begin{array}{l}\text { Plasma } \\
\text { insulin } \\
(\mathrm{mU} / \mathrm{l})\end{array}$ & $\begin{array}{l}\text { Kidney } \\
\text { weight } \\
\text { (g/kg body } \\
\text { weight) }\end{array}$ & $\begin{array}{l}\text { Glucose-6-P } \\
\text { dehydrogenase } \\
\text { (U/100 g body } \\
\text { weight) }\end{array}$ & $\begin{array}{l}\text { Pyruvate } \\
\text { kinase } \\
\text { (U/100 g } \\
\text { body weight) }\end{array}$ & $\begin{array}{l}\text { Fructose- } 1-6 \\
\text { diphosphatase } \\
\text { (U/100 } \mathrm{g} \\
\text { body weight) }\end{array}$ & $\begin{array}{l}\text { Glucose- } 6 \\
\text { phosphatase } \\
\text { (U/100g } \\
\text { body weight) }\end{array}$ \\
\hline Starch-fed $(n=8)$ & $6.2 \pm 0.1$ & $43.4 \pm 3.2$ & $6.7 \pm 0.1$ & $1.25 \pm 0.11$ & $11.2 \pm 0.4$ & $3.91 \pm 0.33$ & $0.10 \pm 0.01$ \\
\hline Sucrose-fed $(n=9)$ & $7.3 \pm 0.3^{\mathrm{a}}$ & $54.7 \pm 8.4$ & $7.2 \pm 0.2^{\mathrm{b}}$ & $1.55 \pm 0.16$ & $14.8 \pm 1.2^{\mathrm{a}}$ & $5.03 \pm 0.41^{\mathrm{a}}$ & $0.14 \pm 0.02$ \\
\hline $\begin{array}{l}\text { Starch-fed } \\
\text { diabetic }(n=11)\end{array}$ & $34.1 \pm 2.4$ & $5.5 \pm 0.8$ & $13.5 \pm 0.4$ & $2.50 \pm 0.20$ & $26.5 \pm 1.8$ & $8.57 \pm 0.88$ & $0.29 \pm 0.03$ \\
\hline $\begin{array}{l}\text { Sucrose-fed } \\
\text { diabetic }(n=9)\end{array}$ & $31.7 \pm 2.3$ & $7.5 \pm 1.2$ & $16.8 \pm 0.9^{b}$ & $3.27 \pm 0.35$ & $39.7 \pm 3.9^{b}$ & $10.14 \pm 1.06$ & $0.55 \pm 0.10^{\mathrm{b}}$ \\
\hline Diet & NS & NS & $p<0.05$ & NS & $p<0.01$ & NS & $p<0.05$ \\
\hline Diabetes & $p<0.001$ & $p<0.001$ & $p<0.001$ & $p<0.001$ & $p<0.001$ & $p<0.001$ & $p<0.001$ \\
\hline Diet $\times$ diabetes & NS & NS & $p<0.01$ & NS & $p<0.01$ & NS & NS \\
\hline
\end{tabular}

Values are expressed as mean $\pm \mathrm{SEM}$,

a Values for sucrose-fed rats significantly different from starch-fed rats $(p<0.005)$,

${ }^{\mathrm{b}}(p<0.01)$

Enzyme activities: The left kidney was homogenised in five volumes of ice-cold $0.15 \mathrm{~mol} / 1 \mathrm{KCl}$ and the homogenates were centrifuged at $15,000 \mathrm{~g}$ for $30 \mathrm{~min}$ at $4{ }^{\circ} \mathrm{C}$. The supernatant was used to measure the activities of glucose-6-P dehydrogenase (G-6-PDH) [10], pyruvate kinase (PK) [11], fructose-1-6-diphosphatase (FDPase) [12] and glucose-6-phosphatase (G-6-Pase) [13].

Lipogenesis in vivo: Synthesis of fatty acids were measured $1 \mathrm{~h}$ after an IP injection of ${ }^{3} \mathrm{H}_{2} \mathrm{O}(1.5 \mathrm{mCi} / 100 \mathrm{~g}$ body weight in $0.9 \% \mathrm{NaCl}$, $0.1 \mathrm{ml} / 100 \mathrm{~g}$ body weight) [14].

Statistical analysis: The data were subjected to a two-way analysis of variance (ANOVA) to assess the effect of diet and of diabetes, and the interaction between the two. Due to non-homogeneity of variance, some data were transformed into common logarithms prior to analysis. The significance of differences between individual means was tested by Student's t-test.

\section{Results}

In agreement with results presented previously [3] in two separate experiments, the feeding of sucrose did not affect gain in body weight by the rats or their apparent well-being compared with rats fed starch. However, sucrose produced heavier kidneys than did starch (Table 1). Streptozotocin-induced diabetes led to impaired growth and kidney weights relative to body weight were increased. Analysis of variance disclosed a significant interaction $(p<0.05)$ between the effects of sucrose and diabetes on kidney weights. The streptozotocin-treated rats remained diabetic as judged by the presence of hyperphagia, polydypsia, polyuria and glucosuria, and were markedly hyperglycaemic at the end of the experiment (Table 1), blood glucose concentrations being negatively correlated with insulin concentrations $(r=-0.83, p<$ $0.001)$.

\section{Enzyme Activities}

In the first experiment (Table 1), we compared the influence of diet and diabetes on individual enzymes in the kidney whose activities provide either an index of the potential rate of provision of substrate (pyruvate kinase) or reducing equivalents (glucose-6-P dehydrogenase) for lipogenesis, or an index of the potential rate of gluconeogenesis (fructose-1,6-diphosphatase, glucose-6-phosphatase). Our results are expressed as enzyme units per $100 \mathrm{~g}$ body weight, a measure that relates biochemical activity to the functional requirement of the whole animal [15]. It is particularly necessary to consider the results in this manner when comparing diabetic rats whose body weight gain is impaired and where liver weight shows a moderate decrease but kidney weight an increase.

Diabetes significantly increased the activities of FDPase $(p<0.001)$ and G-6-Pase $(p<0.001)$; G-6$\mathrm{PDH}$ and PK activities were also enhanced ( $p<$ $0.001 ; p<0.001)$. The response was qualitatively similar when enzyme activities were expressed per unit weight of protein but the physiological effect of diabetes was then underestimated because the use of unit weights cannot take into account the large increment in kidney size. The effect of sucrose feeding was to increase all enzyme activities although the enhancement of G-6-PDH and G-6-Pase did not attain statistical significance in normal animals and the change in G-6-PDH and FDPase activities was not significant in diabetic rats. The enhancement of PK activity by sucrose was greater in the diabetic rats as reflected by the significant interaction between sucrose and diabetes $(p<0.01)$. 


\section{Fatty Acid Synthesis}

In the second long-term experiment, we attempted to confirm the changes observed for the key enzymes potentially indicative of the rate of lipogenesis (G-6$\mathrm{PDH}, \mathrm{PK}$ ) by measuring the total mass of fatty acid synthesised in vivo, $1 \mathrm{~h}$ after the administration of ${ }^{3} \mathrm{H}_{2} \mathrm{O}$.

Sucrose-feeding enhanced hepatic fatty acid synthesis in both normal $(p<0.05)$ and diabetic rats $(p<$ 0.01 ), the rate was decreased by diabetes using either diet. The response measured in the kidney was in agreement with the results of the enzyme activities; fatty acid synthesis was increased by diabetes, although the change reached statistical significance only in the sucrose-fed rats. Fatty acid synthesis was also increased by sucrose-feeding although the change reached statistical significance only in the diabetic rats. The interaction between sucrose and diabetes was significant in liver $(p<0.01)$ and kidney $(p<$ 0.05 ). Thus the combination of the two factors appeared synergistic and was associated with a large increase in the accumulation of total lipid in the kidney (Table 2).

\section{Acute Effects}

To determine whether the effect of the diabetic state on the rate of fatty acid synthesis in the kidney relative to the liver is maintained under different conditions, we also examined, in experiment 3 , the acute response to alloxan in stock-fed rats of a different strain. Diabetes was characterised by hyperglycaemia (Table 3 ) and by polyuria, glycosuria and by an increased intake of water. In this acute experiment, diabetes had little influence on liver and kidney weight relative to total body weight, so that lipid synthesis has been expressed per unit wet weight of tissue. Similar changes were noted when tissue activities were expressed per $100 \mathrm{~g}$ body weight. In agreement with the longer-term experiments, diabetes significantly inhibited fatty acid synthesis in the liver and increased the rate in the kidneys.

\section{Discussion}

The results for enzyme activity and rate of lipogenesis for the long-term experiments are expressed per $100 \mathrm{~g}$ body weight, a procedure which has been considered to provide the best means of comparing diabetic animals with their age-matched controls [15]. If the results are expressed, for example, per unit wet weight then there is no effect of diabetes on either the potential or actual rate of renal lipogenesis but we feel that
Table 2. Kidney total lipids and fatty acid synthesis in normal and diabetic rats fed starch or sucrose diet

\begin{tabular}{|c|c|c|c|}
\hline Rats & $\begin{array}{l}\text { Kidney total } \\
\text { lipids (mg/kg } \\
\text { body weight) }\end{array}$ & $\begin{array}{l}\text { Liver fatty } \\
\text { acid synthesis } \\
\text { ( } \mu \mathrm{g} / \mathrm{h} \text { per } 100 \mathrm{~g} \\
\text { body weight) }\end{array}$ & $\begin{array}{l}\text { Kidney fatty } \\
\text { acid syn- } \\
\text { thesis }(\mu \mathrm{g} / \mathrm{h} \\
\text { per } 100 \mathrm{~g} \\
\text { body weight })\end{array}$ \\
\hline $\begin{array}{l}\text { Starch-fed } \\
(n=8)\end{array}$ & $79 \pm 3$ & $3,280 \pm 660$ & $30 \pm 3$ \\
\hline $\begin{array}{l}\text { Sucrose-fed } \\
(n=8)\end{array}$ & $83 \pm 3$ & $5,900 \pm 1,300^{\mathrm{a}}$ & $36 \pm 4$ \\
\hline $\begin{array}{l}\text { Starch-fed } \\
\text { diabetic } \\
(n=8)\end{array}$ & $183 \pm 10$ & $390 \pm$ & $38 \pm 4$ \\
\hline $\begin{array}{l}\text { Sucrose-fed } \\
\text { diabetic } \\
(n=8)\end{array}$ & $268 \pm 16^{\mathrm{b}}$ & $2,960 \pm 700^{b}$ & $74 \pm 10^{b}$ \\
\hline Diet & $p<0.01$ & $p<0.001$ & $p<0.001$ \\
\hline Diabetes & $p<0.001$ & $p<0.001$ & $p<0.001$ \\
\hline Diet $\times$ diabetes & $p<0.05$ & $p<0.01$ & $p<0.05$ \\
\hline
\end{tabular}

Values are expressed as mean \pm SEM,

a Values for sucrose-fed rats significantly different from starch-fed rats $(p<0.05)$

${ }^{\mathrm{b}}(p<0.01)$

Table 3. Fatty acid synthesis in alloxan-diabetic and control (stock diet) rats

\begin{tabular}{lcl}
\hline & $\begin{array}{l}\text { Control rats } \\
(n=7)\end{array}$ & $\begin{array}{l}\text { Diabetic rats } \\
(n=9)\end{array}$ \\
\hline $\begin{array}{l}\text { Blood glucose }(\mathrm{mmol} / \mathrm{l}) \\
\begin{array}{l}\text { Fatty acid synthesis } \\
(\mu \mathrm{g} / \mathrm{h} \text { per })\end{array}\end{array}$ & $6.3 \pm 0.07$ & $28.3 \pm 4.2^{\mathrm{b}}$ \\
$\quad \begin{array}{l}\text { Liver } \\
\text { Kidney }\end{array}$ & $289 \pm 61$ & $108 \pm 16^{\mathrm{b}}$ \\
\hline
\end{tabular}

Values are expressed as mean \pm SEM,

a Values for diabetic rats significantly different from values for normal rats $(p<0.01)$

${ }^{\mathrm{b}}(p<0.001)$

this method of calculation underestimates the response and leads to a conclusion at variance with the effect of acute diabetes (Table 3). As the physiological use of circulating substrates by the whole kidney depends on the tissue weight with respect to body weight, we agree with Sochor and co-workers [15] that it is correct to take account of the changes both in tissue weight and body weight. Similarly, the increase in gluconeogenesis is only of physiological significance in terms of the contribution made by the kidney to metabolism overall.

In the kidney, the increased potential for gluconeogenesis after streptozotocin-induced diabetes is in 
agreement with other findings [4] and suggests a role for the kidney in the overproduction of glucose. A similar effect on renal gluconeogenesis was produced by sucrose-feeding, resulting from the ability of the kidney to convert fructose to glucose [16].

Whereas sucrose-feeding also increased renal lipogenesis in parallel with the changes in the liver, we found that the effect of diabetes on fatty acid synthesis was dissimilar at the two sites. This novel finding applied both to acute and, to a smaller extent, chronic diabetes and the qualitative response was independent of diet. The increase in fatty acid synthesis, measured by ${ }^{3} \mathrm{H}$ incorporation, tended to be smaller than the changes observed in individual enzyme activities. This may be related to a simultaneous increase in fatty acid oxidation [17] resulting in a smaller net accumulation of radiolabelled fatty acid.

Whilst the effect of diabetes on the liver can be attributed to the insulin sensitivity of that organ and the effect of sucrose-feeding attributed to substrate flux, the control of events in the kidney is less clearcut. Hormonal control is probably of greater importance in hepatic gluconeogenesis [18] than in the kidney, where the availability of specific substrate determines the rate of gluconeogenesis [19]. Moreover, insulin is not required for renal phosphorylation of glucose by hoxokinase [20] so that the rates of glycolysis and lipogenesis may reflect the high blood glucose concentration. Furthermore, the diabetic kidney has a greater requirement for fatty acid to synthesise phospholipid for new membrane during hypertrophy and, perhaps, also for the thickening basement membrane.

The additive, possibly synergistic, effects of dietary sucrose and diabetes on fatty acid synthesis and lipid accumulation are of particular interest and may be explained, in part, by the hyperphagia found in diabetes with the consequent increased requirement for disposal of fructose.

We conclude from the present results that sucrosefeeding and diabetes have qualitatively similar effects on renal lipogenesis in support of previous findings [1] for similarity as regards the modification of glomerular basement membrane. The potency of the interaction between sucrose and diabetes underlines the usefulness of this carbohydrate in models for the study of biochemical mechanisms in diabetes.

\section{References}

1. Taylor SA, Price RG, Kang SS, Yudkin J (1980) Modification of the glomerular basement membrane in sucrose-fed streptozotocin-diabetic rats. Diabetologia 19:364-372

2. Bruckdorfer KR, Khan IH, Yudkin J (1972) Fatty acid synthetase activity in the liver and adipose tissue of rats fed various carbohydrates. Biochem J 129:439-446
3. Bruckdorfer KR, Kang SS, Khan IH, Bourne AR, Yudkin J (1974) Diurnal changes in the concentrations of plasma lipids, sugars, insulin and corticosterone in rats fed diets containing various carbohydrates. Horm Metab Res 6:99-106

4. Murphy ED, Anderson JW (1974) Tissue glycolytic and gluconeogenic enzyme activities in mildly and moderately diabetic rats: influence of tolbutamide administration. Endocrinology 94:27-34

5. Lin WJ, Anderson JW (1977) Effects of high sucrose or starchbran diets on glucose and lipid metabolism of normal and diabetic rats. J Nutr 107:584-595

6. Bender AE, Damji KB, Yapa CGR (1970) Effect of dietary sucrose on the metabolism in vitro of liver from rats of different strains. Biochem J 119:351-352

7. Cohen AM, Briller S, Shafrir E (1972) Effect of long-term sucrose feeding on the activity of some enzymes regulating glycolysis, lipogenesis and gluconeogenesis in rat liver and adipose tissue. Biochim Biophys Acta 279: 129-138

8. Weber G, Singhal RL, Stamm NB, Fisher EA, Mentendiek MA (1964) Regulation of enzymes involved in gluconeogenesis. Adv Enzyme Regul 2: 1-38

9. Hales CN, Randle PJ (1963) Immunoassay of insulin with antibody precipitate. Biochem J 88: 137-146

10. Luhr GW, Waller HD (1974) Glucose-6-phosphate dehydrogenase. In: Bergmeyer HU (ed) Methods of enzymatic analysis. Academic Press, New York, pp 636-643

11. Bücher T, Pfleiderer G (1955) Pyruvate kinase from muscle. Methods Enzymol 1:435-440

12. Latzko E, Gibbs H (1974) Alkaline $C_{1}$-fructose-1,6-diphosphatase. In: Bergmeyer HU (ed) Methods of enzymatic analysis. Academic Press, New York, pp 881-884

13. Baginski ES, Foà PP, Zak B (1974) Glucose-6-phosphatase. In: Bergmeyer HU (ed) Methods of enzymatic analysis. Academic Press, New York, pp 876-880

14. Fears R, Umpleby AM (1979) Evidence for the operation of the extrahepatic lipoprotein receptor system in vivo in rats. Biochem J 182: 803-809

15. Sochor M, Baquer NZ, McLean P (1979) Glucose overutilization in diabetes: evidence from studies on the changes in hexokinase, the pentose-phosphate pathway and glucuronate-xylulose pathway in rat kidney cortex in diabetes. Biochem Biophys Res Commun 86:32-39

16. Flinn RB, Leboeuf B, Cahill GF (1961) Metabolism of ${ }^{14} \mathrm{C}$-labelled substrates in kidney cortical slices from normal and alloxan-diabetic rats. Am J Physiol 200: 508-510

17. Ross J, Goldman JK (1971) Effect of streptozotocin-induced diabetes on kidney weight and compensatory hypertrophy in the rat. Endocrinology 88: 1079-1082

18. Scrutton MC, Utter MF (1968) The regulation of glycolysis and gluconeogenesis in animal tissues. Annu Rev Biochem 37: 249-302

19. Cohn C, Kolinsky M (1949) Effect of blood sugar levels and insulin lack on gluconeogenesis by the kidney of the dog. Am J Physiol 156:345-348

20. Katzen HM (1967) The multiple forms of mammalian hexokinase and their significance to the action of insulin. Adv Enzyme Regul 5:335--356

Received: 11 February 1981

and in revised form: 27 November 1981

Dr. R. Fears

Beecham Pharmaceuticals Research Division

Great Burgh

Epsom, Surrey KT18 5XQ, UK 